\title{
Financing Risk Analysis and Countermeasure Research of Hi-tech Enterprises
}

\author{
Xiurong Li*, Hexiang Fan, Congcong Cao \\ School of business, Northwest University of Politics and Law, Xi'an 710122, China
}

\begin{abstract}
Basing on the definition of the concept of hi-tech enterprises, this paper characterizes the financing risk of hi-tech enterprises as informational asymmetric, highly uncertain, and lack of collateral. Risk analysis is conducted employing the theory of enterprise life cycle and the theory of information asymmetry. Risk identification is then discussed in debt financing and equity financing. To conclude, this paper proposes several ways to better deal with financing risks from the perspective of enterprises, financial markets and government regulation.
\end{abstract}

Keywords: Hi-tech enterprises; Financing risks; Countermeasures

\section{Introduction}

Innovation is the core of the national and social progress. Including the China, all the world keep the development of hi-tech industry as the key point of strategy. In the nineteen major reports of the Communist Party of China, it clearly put forward the implement of innovation driven development strategy, promoting the transformation of scientific and technological achievements in science and technology system and mechanism innovation, training the innovative scientific and technological personal team building.

After entering 21 st Century, the hi-tech enterprises have achieved rapid development with the support of the government, and have carried more and more important roles in the national economy and become an important economic force in the construction of modernization. But income and risk coexist, and high yield is accompanied by high risk. The investors and banks of risk aversion are particularly prudent to the investment decision of the hi-tech enterprises, which causes the external financing difficulties of the

*Corresponding author's: 13572169974@163.com enterprises, and then affects the speed of the development of the enterprises.

Comparing with the western developed countries, the development of hi-tech enterprises is relatively backward in China, which due to the lack of large capital support. In general, there are more than 30 thousand patent technologies in China each year, because of the shortage of funds and other factors, which are converted into products and form a scale economic effect only $10 \%-15 \%$, far below the level of $60 \%-80 \%$ in the developed countries( Zhao,2013). Because of the lack of financing risk awareness, the most hi-tech enterprises can not effectively identify and evaluate the financing risk, and can not carry out effective risk management, thus affecting the space for their survival and development. Therefore, how to identify and analyze the financing risks of the hi-tech enterprises, how to improve the financing difficulties, which have become a very valuable research topic.

David Durant put forward the theory of capital structure in 1952, it proposed if the debt financing is in a certain proportion, the debt cost will not bring about the increase of the equity financing cost and it also include the equity. If the proportion of enterprise's debt exceeds a certain range, the risk will rise. The equity of the enterprise and the debt capital also will rise. Modigliani and Miller put forward the classical MM theorem in 1958, which has two theorems. Firstly, when the debt risk is low, if the enterprise changes the capital structure to increase the debt rate, it can increase the rate of return of the equity. Secondly, the rate of earnings per share of the indebted enterprise is equal to the rate of capitalization adapted to the pure equity flow at the same risk and the premium associated with its financial risk. It also means that, if it is under the premise of low debt risk, the enterprises can improve the return on equity investment by changing the capital structure, it also will rise the debt ratio. How worth proposed that hi-tech enterprises, when they finance from the outside in 2001. When hitech enterprises get the financing from outside, 
if they pay too much attention to the control power, it can not completely follow the general order of financing. that is, the normal financing order of the equity after the first creditor's right. Lin and Li (2001) proposed the existence of information asymmetry. The hitech enterprises have infringed the rights and interests of fund providers on the basis of their own information superiority and the use of funds after the event, and it will result the moral hazard and adverse selection. This is a major cause of financing difficulties for hitech enterprises. They expounded the practical significance of promoting the development of the hi-tech enterprises to the China's economy. They also put forward that the healthy and rapid development of small and medium-sized financial institutions is an important way to solve the problem of financing difficulties of hi-tech enterprises. Quan and Wang ( 2011) analyzed the financial risk of hi-tech industry from the perspective of financing risk. They put forward that the financing risks are different from other industries because of the characteristics of low income, high investment and high uncertainty in the market. They also put forward the corresponding precautionary measures to deal with the financing risks. From the point of view of enterprise management, Tian (2013) analyzes the reasons for the difficult financing of hi-tech enterprises, and puts forward that it is a decisive factor to improve the financing risk of hi-tech enterprises by improving their own management strength. From the perspective of government management, Zhao (2016) put forward the construction strategy of the government's financing service system for hitech enterprises, and expounded the fundamental reasons for the financing difficulty of hi-tech enterprises. Wang et al.(2007) explored the financing risks of hitech enterprises through quantitative analysis of the financing risks of hi-tech enterprises from the perspective of capital cost and capital structure.

Through the above research, it shows that the hi-tech enterprises have the financing risk due to their light assets and small scale, but the existing research lacks a systematic discussion on how to identify the financing risks of hitech enterprises and does not have a comprehensive discussion on how to deal with the risks of hi-tech enterprises. This paper will mainly study the concept of hi-tech enterprises, and the characteristics of hi-tech enterprise financing risk and how to identify and deal with the financing risks of hi-tech enterprises.
2. An overview of the financing risks of hitech enterprises

2.1 Definition of the concept of hi-tech technology enterprises

"The notice on the revision and issuance of the management measures for the identification of hi-tech enterprises" stipulates that "the hi-tech enterprises referred to in the present measures refer to the enterprises that the continuous R \& D and transformation of technical achievements in the state key supported hi-tech technology fieldsand the formation of the core independent intellectual property rights of the enterprise, and on this basis, to carry out business activities, to register enterprises in China (excluding Hong Kong, Macao and Taiwan)".

\subsection{Characteristics of hi-tech enterprises}

\subsubsection{Small scale}

China's hi-tech enterprises are mainly small and medium-sized, and the number of personnel is generally not more than 100 . The stability of personnel is weaker than that of large enterprises. Whether external or internal environment changes, the impact on enterprises is greater than that of large enterprises.

\subsubsection{High dependence on individuals}

Hi-tech enterprises are technology intensive and knowledge intensive enterprises. Talents are the key resources of hi-tech enterprises. Therefore, human resources play a key and core role in the development of hitech enterprises. The high dependence on talents brings huge business risks to hi-tech enterprises, and the loss of core technical talents may cause a devastating blow to enterprises.

\subsubsection{High investment and high risk}

High investment in hi-tech enterprises is mainly shown in the process of $\mathrm{R} \& \mathrm{D}$ and commercialization, which requires a large amount of funds, and the more difficulty of $\mathrm{R}$ $\& \mathrm{D}$, the more funds need to be invested. The high risk of hi-tech enterprises refers to the rapid development of new and high technology products, the uncertainty of the market demand and the high degree of talent dependence, which causes the business risk to be increased.

\subsubsection{High growth and high income}

Once the products of hi-tech enterprises are 
recognized by the market, because of the protection of intellectual property, the enterprises will bring huge market competitive advantage. The products and services seize the market rapidly because of the technology lead. The return on investment may increase several times, tens times even hundreds of times in a few years. In a short period of time, it has grown into a large or even Unicorn enterprise. Jumping development is an important feature of hi-tech enterprises.

\subsection{Definition of financing risk of hi-tech enterprises}

Risk is defined by the lack of experience and expertise of personnel who are participants of a project (Kashiwagi and Kashiwagi 2012). The financing risk of hi-tech enterprises refers to the risk of capital loss and loss of shareholders' rights and interests caused by the failure of financing or failure of technology commercialization after the success of financing.

\subsection{Characteristics of financing risk of hi-} tech technology enterprises

Compared with the financing risk of general enterprises, the financing risks of hitech enterprises are significant.

\subsubsection{Information asymmetry.}

Because of the characteristics of "hi-tech technology", hi-tech enterprises can not provide sufficient and transparent enterprise information like large enterprises because of the needs of enterprise management such as intellectual property protection. Because of the existence of information asymmetry, the investment of banks and investors on hi-tech enterprises is more prudent, which leads to the increase in the difficulty of enterprise financing.

\subsubsection{High uncertainty.}

The products of hi-tech enterprises, from $\mathrm{R}$ $\& \mathrm{D}$ to test and then to product, have great uncertainty at each stage, and any problem in any stage may lead to the failure of business. Its high operating uncertainty makes financing difficult.

\subsubsection{Light capitalization and lack of} collateral.

The assets of hi-tech enterprises are mainly intangible assets such as patents, trademarks, copyrights, and other intangible assets such as fixed assets are relatively low, while banks and other lending institutions require enterprises to provide considerable collateral. Owing to their characteristics of light assets, enterprises are unable to provide sufficient collateral, and it is difficult to obtain financing from institutions such as banks.

\section{Basic theory of financing risk of hi-tech enterprises.}

\subsection{Theory of enterprise financial growth cycle}

The theory of enterprise financial growth cycle is based on the theory of enterprise life cycle, which is based on Brigham and Weston, which can choose different financing ways according to the different life cycle of the enterprise. The two factors divide the financial growth cycle into the initial stage, the development stage one, the development stage two, the development stage three, the mature stage and the recession stage six stages. As shown in Table 1.

According to this theory, enterprises should adopt corresponding financing strategies according to their own different stages of development. When the enterprise is

Table 1: Enterprise financial growth cycle

\begin{tabular}{ccc}
\hline Stage & Source of financing & Potential problems \\
\hline Initial stage & Enterprise own capital & Lower capitalization \\
Development stage one & $\begin{array}{c}\text { Enterprise own capital,internal } \\
\text { accumulation, bank loan, lease } \\
\text { Above sources+ long-term } \\
\text { Development stage two }\end{array}$ & Stock backlog \\
& $\begin{array}{c}\text { financing from banks and other } \\
\text { financial institutions }\end{array}$ & Financial gap \\
Development stage three & Above sources+ equity & Decentralization of control \\
Mature stage & financing + debt financing & All the above sources \\
Recession stage & Stock repurchase, merger, & Operate conservatively \\
& acquisition, bankruptcy, etc & Diminishing returns \\
\hline & Source: Weston \& Brigham, 1978 &
\end{tabular}


in its initial stage, the market share is low, the financial norm is poor, the human property is relatively weak, and the information of the enterprise is relatively closed. Enterprises in initial stage mainly rely on entrepreneur investment and endogenous financing. When enterprises enter the development period, their business ability has been improved, and enterprises have a certain market competitiveness in goods and technology, and information is more transparent. When the enterprise enters the mature stage, the financial system is more perfect and the market share is relatively stable, and gradually satisfies the conditions of the listed financing.In this stage, the enterprises issue stock financing to the investors and investment institutions of the securities market as their main financing way.

\subsection{Theory of information asymmetry}

The theory of information asymmetry means that in economic activities, there is a difference in the mastery of information by all the parties in the market. Those who know more information are always in a relatively advantageous position, while the party whose information is lacking is in a relatively unfavorable position. The theory of information asymmetry is put forward by three American economists, George acllov, Michael Spence and Joseph Stiglitz (Xanthos 2014). The theory holds that the seller has more information about the goods in the market than the buyer; the party who knows more information can benefit from the transfer of information to the party that is lacking in information, and the party who has less information in the buyer and seller will actively seek information from the other side.

Each enterprise can know the bank's credit policy and other information through open channels, but because the information of the non public enterprise is concealed, the bank can not fully grasp all the information of the enterprise, the bank is in the situation of information inferiority, the enterprise has the credit advantage, Information asymmetry exists between the two sides in the credit relationship.

Because information asymmetry exists between enterprises and banks, it is easy to cause adverse selection. No matter how high financing costs and conditions the company is willing to pay, banks will not grant loans to enterprises. It is possible for enterprises to use the advantage of information asymmetry to put the financing funds into a low efficiency business and bring financial risk.

\section{Identification of financing risk of hi-tech enterprises}

The systematic classification and analysis of potential risks that the enterprises are facing but have not yet occurred, and then the process of recognizing and distinguishing is the risk identification of the enterprise. This paper divides the financing risk of hi-tech enterprises into two categories: debt and equity financing from different financing methods.

\subsection{Risk identification of debt financing}

Debt financing refers to the integration of new and hi-tech enterprises by means of issuing bonds or bank loans through non bank financial institutions. The main debt financing methods adopted by hi-tech enterprises include bank loans and business credit.

\subsubsection{Bank loan financing risk}

Hi-tech enterprises face the main risk of loan financing: because of the characteristics of hi-tech enterprises, such as the characteristics of the light assets can not fully meet the loan conditions of the bank, can not obtain bank loan funds; the income of financing income has not reached the expectation but can not return to the normal repayment of interest. Enterprises are more likely to get into financial difficulties because of these risks.

(1) Hi-tech enterprises are unable to obtain loans from banks because they can not meet the relatively stringent loan requirements of banks. Banks generally require enterprises to provide third party guarantees or necessary collateral when applying for loans, while the assets of hi-tech enterprises are mainly intangible assets such as copyright, patent and so on, and the assets of fixed assets are relatively less, which leads to the collateral that cannot be provided by the bank. At the same time, the credit system of our country is not yet perfect. Under the condition of asymmetric information, guarantee institutions will not guarantee the hi-tech enterprises easily.

(2)The proceeds from the financing of hitech enterprises are not up to expectations and are unable to repay principal and interest normally. The uncertainty of the operation of hi-tech enterprises is high. If the enterprises invest all the loan funds in the technological research and development process, once the $\mathrm{R}$ \& D failure or the product is not accepted by the market, the expected funds will not be realized, and the enterprises will not be able to repay the interest and the principal. 


\subsubsection{Risk of commercial credit financing}

Business credit refers to the credit form between enterprises based on trust and trust between enterprises, which is closely related to commodity transactions. It mainly includes the credit provided in the form of installment, credit and so on, as well as the credit established on the basis of commodity transaction by deferred payment or prepayment.

The risk of commercial credit financing is a kind of debt financing risk of hi-tech enterprises, which shows that, because of the information asymmetry and the need of risk management, the suppliers of enterprises are reluctant to sell goods on credit to the enterprises or their customers and agents who are reluctant to pay the prepayment to the enterprise, or after obtaining financing funds, a credit risk that can not be paid on schedule.

(1) Suppliers of enterprises are unwilling to sell goods on credit to enterprises or enterprises' customers and agents, and are unwilling to pay advance payments to enterprises. Because the information transparency of the hi-tech enterprises is low, the scale is small, and the technology R \& D, the product, and the market recognition form the uncertainty in the income process, the enterprises' suppliers are not willing to sell the goods on credit to the enterprises. At the same time, the enterprises' customers and agents will not easily pay the advance payment to the hitech enterprises because of the rapid technological innovation, the emergence of the replacement products and the high uncertainty of the market acceptance.

(2) After obtaining the financing, it will also bear the risk of undue payment. After selling goods on credit to hi-tech enterprises by the suppliers of enterprises, the enterprises to convert the goods into sales income also have to experience the links of product, mass production and market development. Any problem in one link may lead to the failure of the product and aggravate the financial cost of the enterprise; the customers and agents of the enterprise pay the prepayment to the enterprise. After the payment, the enterprises put the financing income into production, and the production process is pause because of the equipment failure or the shortage of raw materials. The product delivery can not be carried out on time, damaging the company's goodwill, and the refinancing of the enterprise will be more difficult.

\subsection{Risk identification of equity financing}

Equity financing is achieved by increasing shareholder equity, such as issuing stocks, introducing new investors, and increasing investment. Risk analysis of equity financing will be carried out from two aspects: venture capital and issuing stock.

\subsubsection{Venture investment risk}

Venture capital is the investment of investors with capital strength to support the founders who have the core technology and have good market prospects, but lack the startup capital, and help them to realize the ideal of entrepreneurship, and thus take on the risk of the possible failure of the investment in the start-up stage. The funds invested by the investor are exchanged for part of the shares of the enterprise, and the purpose is to obtain dividends or transfer the shares to obtain investment appreciation in the future.

The risk of venture capital is mainly reflected in the characteristics of the phased investment of venture capital in batches. Generally speaking, venture capitalists will inject capital into stages and step by step according to the actual development of enterprises, instead of investing in enterprises at the beginning stage. Therefore, venture capitalists mainly look at the development of enterprises, that is growth, to decide whether they will continue to invest. As hi-tech enterprises are high risk industries, enterprises can not ensure that each stage target can be realized as scheduled. Once enterprises can not achieve the established stage goals, venture investors may not continue to invest in the decision, enterprises have to carry out a new round of financing, thus bringing a new round of financing risk.

In addition, venture capital investing in enterprises will bring new ideas, rich industry resources and excellent talents to enterprises. Once the enterprise can not complete the stage goal to lead to the withdrawal of venture capital, because of the high dependence of the enterprise on these resources, it may lead to the confusion of the enterprise management, and even the long-term development of the enterprise.

\subsubsection{Stock financing risk}

The stock financing means that the fund does not pass through the bank and other financial institutions, through the stock as a tool from the fund provider directly to the capital demand side, and the fund provider, as 
the shareholder (owner), has the right to vote or control the shareholders of the enterprise.

The risk of stock financing means that in the process of financing by the stock, the company does not have the right opportunity to choose the right time, the amount of the stock is not appropriate, the cost of financing is too high to bring the loss to the company, and the stock price is brought under the stock price because the operating benefit of the company can not reach the investment return of the investor. The possibility of falling will lead to the difficulty of subsequent refinancing.

(1) The operation of an enterprise suffers from factors such as inappropriate issuance of shares, high cost of financing, and missed opportunities to list. China's capital market is relatively unitary, and the main board market is too demanding. Even if it is the gem, hi-tech enterprises can hardly achieve financing smoothly. Before going on the market, the enterprises need to undergo the process of compliance reform, share reform, and other guidance institutions, such as the sponsor, the law firm, the accounting firm and so on, to further raise the cost of financing. Once the listing has not been approved, the initial investment will not return. In addition, because of the failure to accurately grasp the market environment and intermediary agencies and other reasons, leading enterprises to miss the opportunity to go on the market, enterprises also have to face the risk of failure.

(2) Because the company's economic benefits can not reach the expected return of investment, the company's stock price will be more likely to fall and the company's refinancing is more difficult. Because of the existence of information asymmetry and the "high technology" characteristics of hi-tech enterprises, it is difficult for investors to understand and master all the information of the enterprise. Therefore, investors are afraid to buy this kind of stock easily. There is a high uncertainty in the process of new technology R \& $\mathrm{D}$, the product of technology and the development of the market. Once a problem occurs in a certain link, the business operation will be affected. The economic efficiency of the company can not meet the expectation of investment, and the possibility of the decline of the company's stock will increase, and the subsequent refinancing will be more difficult.

There are many other ways to identify risks, such as environmental analysis, accident analysis and so on. In carrying out risk identification work, enterprises should flexibly use various analytical methods flexibly.

\section{Countermeasure of financing risks of hi-tech enterprises}

5.1 Management of scientific financing decision.

We should establish and improve the management system of enterprises, improve the transparency of enterprise finance, improve the management level of enterprises, and create a good credit environment for financing. At the same time, according to the market environment and the changes in the development stage of the enterprise, we should adjust and select the financing ways and financing channels suitable for the enterprises, and make rational and efficient use of equity financing and debt financing tools.

\subsection{Establish and maintain relations.}

Hi-tech technology enterprises should establish and maintain relations with financial institutions and investment institutions, expand financing channels and grasp every financing opportunity. After obtaining financial support, it is necessary to keep the trust of the bank and other financial institutions, and to obtain longterm financial support and loan support, so as to provide strong financial support for the sustainable development of the enterprises. By establishing trust relationship between banks and enterprises, we can solve the problem of asymmetric information in credit relationship. Through the establishment of trust relations with investment institutions such as Vc firm, the problem of information asymmetry in the investment relationship is solved, and the financial support for the enterprises to achieve considerable development is achieved.

\subsection{Firmly establish the spirit of contract.}

The contract of the enterprise includes the contract between enterprises, enterprises and employees, enterprises and government and between the enterprise and the society, andestablishes and insists on the spirit of contract and improves the credit of the enterprise. By raising the credit rating, we can effectively reduce the financing risks of hitech enterprises and enhance the financing ability of hi-tech enterprises.

\subsection{Attach importance to and strengthen the identification of financing risks.}

The scientific analysis methods, such as the Monte Carlo method and the risk index 
analysis method, are used to predict and monitor the financing risks, and the countermeasures are made in time to resolve the financing risks. We should strengthen supervision and management of controllable factors such as information, technology, personnel and capital, and formulate a detailed and efficient risk identification process.

\subsection{Strengthening information disclosure}

For public companies such as listed companies and new three board listed companies, public companies should strengthen the management of investor relations, maintain close communication with the securities regulatory authorities, fulfill the information disclosure obligations in real, accurate, complete and timely manner, so that the capital market investors can understand the development and key information of the enterprise in a timely manner and prevent the error information, which the risk of equity financing is produced.

\section{Conclusion}

In addition to the countermeasures mentioned above, it is more necessary for enterprises themselves, financial institutions and the government to work together to establish and improve the government support system, the multi-level capital market system and the banking system. We should establish a sound credit system, improve the credit rating of enterprises, select financing channels and financing ways suitable for the development level and development stage of hi-tech enterprises, introduce development funds for hi-tech enterprises, support scientific and technological innovation, and promote the rapid growth and healthy development of hitech enterprises.

\section{Reference}

Kashiwagi D, Kashiwagi J. A new risk management model. Journal of Risk Analysis and Crisis Response, Vol. 2, No. 4 (December 2012), 233-251

Li X, Wang L, Huang Q. Financing Risk Analysis of Hi-tech Enterprises . Jiangsu Business Theory.2007.(9):159-161

Lin Y F, Li Y J. Development of Small and Medium-sized Financial Institutions and Financing of SMEs . Economic Research, 2001 (1):10-12

Modigliani F, Miller M H. The Cost of Capital, Corporation Finance and the Theory of
Investment. American Economic Review, 1958, 48(3):261-297.

Quan W T, Wang M. Analysis and Prevention of Financing Risks in New and High technology Industry . Modern Business. Modern Commercial.2011.(2):38-39

Stiglitz, J E. and Weiss, A. Credit Rationing in Markets with Imperfect Information. American Economic Review, 1981,71(3), 393-410

Tian W B. Causes and Countermeasures of Financing Risks of Hi-tech Enterprises in China, Economics and Management Science, 2013.(8):91

Wang X H. Research on Financing Efficiency of Hi-tech Enterprises in China [D]. Northwestern University.2007

Xanthos F. A Note on the Equilibrium Theory of Economies with Asymmetric Information. Journal of Mathematical Economics, 2014, 55(1):1-3.

Zhao $X$. The financing difficulties and Countermeasures of high-tech enterprises. The modern economic information, 2013 (12): 297-298.

Zhao Z J. The Government's Research on the Strategy of Building up the Financing Service System for Hi-tech Enterprises, China's Hi-tech Technology Enterprises, 2016 (15): 1-2 